\title{
O caso Machado de Assis
}

\author{
Roberto Ventura
}

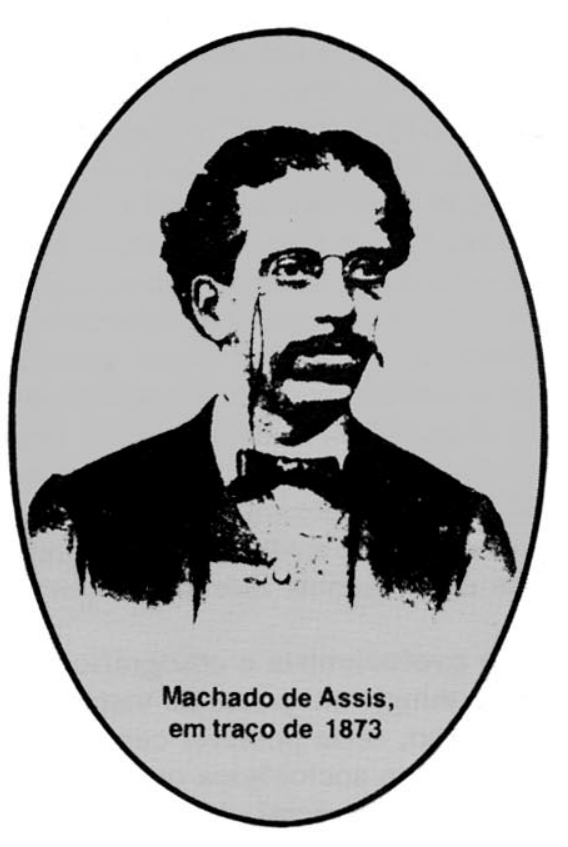

\begin{abstract}
“A virtude prova-se no meio da luta. $A$ sociedade não é um convento de monjas. Que grande mérito advém em não se cobrir de pó a quem não sai à liça do combate e deixa-se tranqüilamente ficar em doce $e$ sossegado aposento?"'
\end{abstract}

(Silvio Romero, Machado de Assis)

\begin{abstract}
“' $O$ observador imparcial, porém, e so pode neste instante ser quem à ausência das paixóes do dia, juntar um grão de ironia e de ceticismo-descobre que efetivamente se faz em torno de si um trabalho de gestação nacionaltstica, como diria o Sr. SIvio Romero."

(José Veríssimo, Estudos brasileiros, $2^{a}$ série)
\end{abstract}

\section{A nova GeraÇÃo E O “ATraso” MaChadiano}

O processo crítico movido por Sílvio Romero contra Machado de Assis se torna um problema para o interprete contemporâneo. Como entender que um dos mais aparelhados críticos da "geração de 1870 " tenha procurado demolir a obra do mais importante escritor da sua época? Sua abordagem da obra de Machado revela tanto as limitações do seu método crítico, orientado por critérios naturalistas e evolucionistas, quanto as motivações subjacentes às polêmicas travadas com seus contemporâneos. Machado não chegou a tomar parte do debate, sendo defendido por Lafaiete Rodrigues Pereira, sob o pseudônimo de Labieno. Essa ausência de participação de Machado não foi gratuita e fez parte da atitude de rejeição às polêmicas, que manteve a partir dos anos 70 .

A polêmica teve, como ponto de partida, o artigo de Machado de Assis sobre a "nova geração", publicado em 1879, na Revista Brasileira. Neste, abordou os novos poetas, dentre eles Romero, cujo "criticismo" poético é tomado como manifesto literário do grupo anti-romântico. No prefácio a Cantos do fim do século (1878), Romero havia

ROBERTO VENTURA é professor do Departamento de Teoria Literária e Literatura Comparada da FFLCH-USP e autor de Bacharéis em luta (Companhia das Letras, no prelo). Este ensaio é uma versăo condensada de um dos capitulos do livro sobre a crítica literária e as polêmicas culturais de 1870 a 1914.

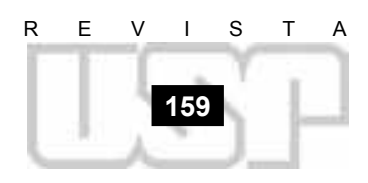


Na página ao lado.

Silvio Romero (1851-1914) em água-forte de G. Bloow
1 "A poesia de hoje", S. Romero, in Cantos do fim do século. RJ, Tip. Fluminense, 1878, p. xii.

2 Trata-se do artigo "A poesia das Falenas", publicado em A crença, pe riódico do Recife, em 30 de maio de 1870. Baseel-me nas indicaçరes de S. Romero na Historia da literatura brasileira. RJ, Garnier, 1902, p. 466. v. 2.2 v.

3 Compendio de historia da literatura brasileira, S. Romero e J. Ribeiro. RJ, Alves, 1906, p. 318. O capftulo sobre Machado, que consta da Historia da literatura brasileira a partir da $3^{2}$ ediçăo (RJ, José Olympio, 1943, 5 v.) fol (RJ, Jose Olympio, 1943, 5 , lol acrescentado por Nelson Ro mero, que selecionou trechos de $\mathrm{Ma}$ chado de Assis (1897). Nelson Rome ro adulterou a Historia, ao incluir diversos escritos, como algumas partes do Compendio, de modo a completála de forma arbitrária.

4 "Sobre Machado de Assis e Luiz Delfino" (1882), S. Romero, in Estudos de literatura contemporanea. RJ, Laemmert, 1885, pp. 231-4.

5 Idem, Ibidem, p. 232. Grifos meus.

6 Machado de Assis: estudo comparativo de literatura brasileira, S. Romero. RJ, Laemmert, 1897, p. 31.

7 Idem, ibidem, p. 32.

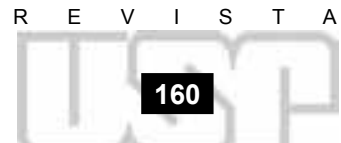

formulado o ideal da "moderna poesia", despojada dos antigos ares de mistério pelas ciências naturais e pela crítica histórica. Essa nova intuição poética deveria se inspirar nos princípios gerais da ciência, sem cair no dogmatismo(1). Mas a "poesia científica" de Romero e Martins Júnior não atingiu tais objetivos, pois se limitava à afirmação didática dos novos credos.

Machado percebeu a fragilidade de tal programa literário. Observou que o interesse dos escritores pela ciência não deveria levar ao pedantismo, resultante da demonstração de novos conhecimentos e do emprego de uma terminologia mal absorvida. Considera faltar "estilo" aos textos críticos e literários de Ś́lvio Romero. Não haveria, em Cantos do fim do século, a definição de forma poética, o que mostraria a sua luta, como escritor, entre o pensamento e a expressão. Além disso, julga exagerada a importância que este atribui aos poetas do Recife, Tobias Barreto e Castro Alves.

O ensaio de Machado de Assis provocou a ira de Sílvio que, por muito menos, se lançava ao ataque dos desafetos e que empenhava sua reputação, como crítico literário, na valorização da Escola do Recife e da obra de Tobias Barreto. Antes de publicar $\mathrm{Ma}$ chado de Assis em 1897, Romero escreveu dois artigos sobre o escritor. Atacou, em 1870, o "lirismo subjetivista" e o "humorismo pretensioso" de Falenas, segundo livro de poemas de Machado $^{(2)}$. Em 1882, criticou a sua filiação ao romantismo, mesclado de resquícios de classicismo, julgando-o um "tipo de transição" entre as antigas concepções e as modernas tendências. Romero não incluiu Machado na História da literatura brasileira, que abrange o período de 1500 a 1870 , da época de formação à última fase do romantismo. Mas manteve, no Compêndio de historia da literatura brasileira (1906), manual escrito com João Ribeiro, as opiniões mantidas em seu livro de $1897^{(3)}$.

Essas censuras a Machado de Assis se orientam por um critério evolucionista, segundo o qual sua obra, fruto de um romantismo tardio, não teria "valor" por estar em desacordo com as tendências contemporâneas. Devido ao seu "atraso", Machado não teria um papel saliente na "evolução intelectual", devendo ser combatido pela "dubiedade de seu caráter político e literário". Sentencia Romero: "É um tipo morto antes do tempo na orientação nacional"(4). Sílvio não percebeu as críticas de Machado ao naturalismo e ao cientificismo, nem a sua ruptura com a estética romântica e realista, sobretudo a partir das Memorias postumas de Brás Cubas, que chama de "bolorento pastel literário".

A ótica evolucionista de Romero se mostra nos comentários sobre Gonçalves de Magalhães, Porto Alegre, Martins Pena, Gonçalves Dias, Álvares de Azevedo, Macedo, Teixeira e Souza: "Os autores que deixei acima lembrados, quaisquer que sejam os seus defeitos, na evolução intelectual brasileira deste século, representam os elos de uma cadeia"(5). Machado, ao contrário, não teria lugar nessa série evolutiva de autores, pelo suposto anacronismo de seu estilo, que mesclaria duas escolas literárias superadas: a romântica e a clássica.

Em Machado de Assis, Romero adotou o critério evolucionista e etnografico, com o fim de enfocar o "povo" ao invés do "indivíduo" e atingir um ponto de vista superior, acima dos rancores, temperamentos e paixões. Com isso, seria possível captar a verdadeira "evolução" das letras e artes e elaborar uma crítica sociológica que abordasse o indivíduo como mediação entre a obra literária e a evolução social, de modo a "descortinar o homem através do livro e a sociedade através do homem"(6).

O "indivíduo" apresenta, na sua concepção, um duplo papel que remete ao naturalismo de Taine e ao evolucionismo de Spencer. Para Taine, o indivíduo é um "espírito representativo", como produto dos fatores naturais e sociais. Por outro, deve atuar sobre a sociedade e a história como "centro de força" ou "fator de diferenciação e progresso", de acordo com os conceitos evolutivos de Spencer. Na concepção de Romero, a literatura se relaciona à sociedade através do indivíduo: "Não basta refletir a sociedade, o principal é agir sobre ela"(7). Sua critica privilegia, portanto, a semelhança entre $o$ indivtduo, a obra e o momento histórico, e não a sua diferença ou originalidade.

Ślvio Romero enviesou sua leitura das obras de Machado a partir do deslocamento do "indivíduo" para o "povo", do livro para a sociedade. A perspectiva naturalista e evolucionista forneceu argumentos que, ao dar uma suposta base cientifica aos julgamentos emitidos, encobre um subjetivismo crítico próximo ao impressionismo. $\mathrm{O}$ criterio evolucionista se torna um rolo compressor que nivela a literatura a uma série evolutiva de estilos e escolas, em que os escritores são valorizados, ou depreciados, a partir do seu grau de correspondência com as tendências eleitas pelo crítico. A partir desse modelo de ação e reação entre literatura e sociedade, Romero considera Machado um escritor "atrasado", incapaz de tomar partido entre as correntes estéticas e filosoficas, 
ensaio de Machado de Assis provocou a ira de Sílvio que, por muito menos, se lançava ao ataque dos desafetos e que empenhava sua repułação, como crítico literário, na valorização da Escola de Recife e da obra de Tobias Barreto

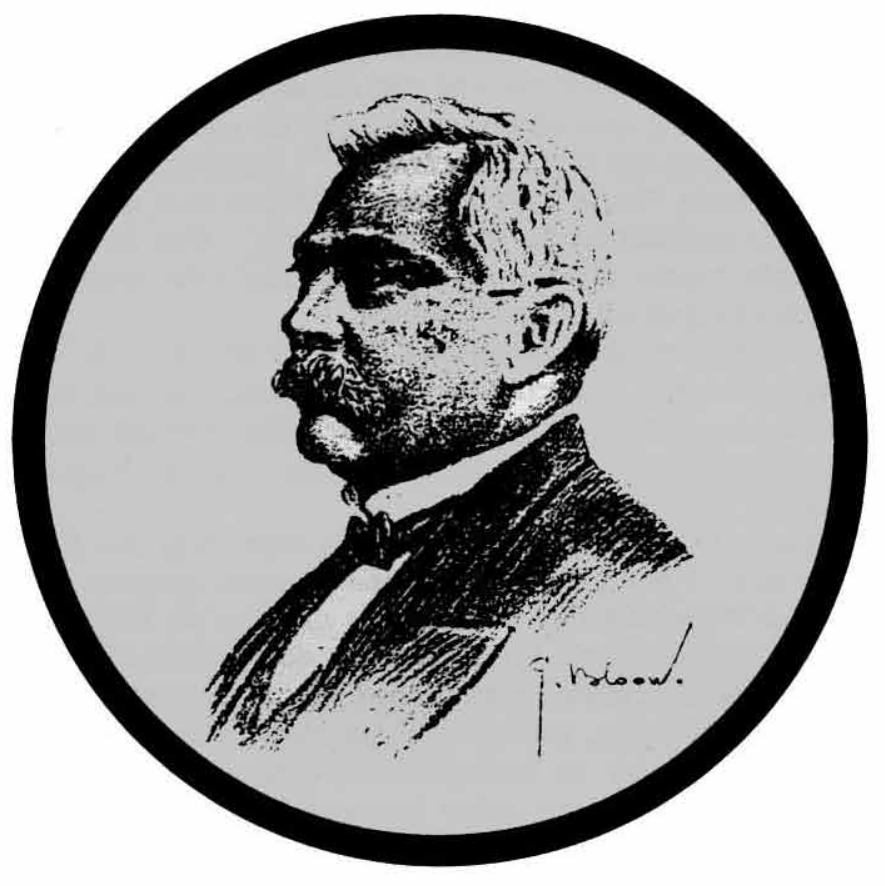

Sílvio atacou o humor e a ironia em Machado, sidos como imitação afetada e pouco natural de autores ingleses, em particular o Laurence Sterne de "The Life and the opinions of Tristram Shandy", que inspirou "Memórias póstumas de Brás Cubas"

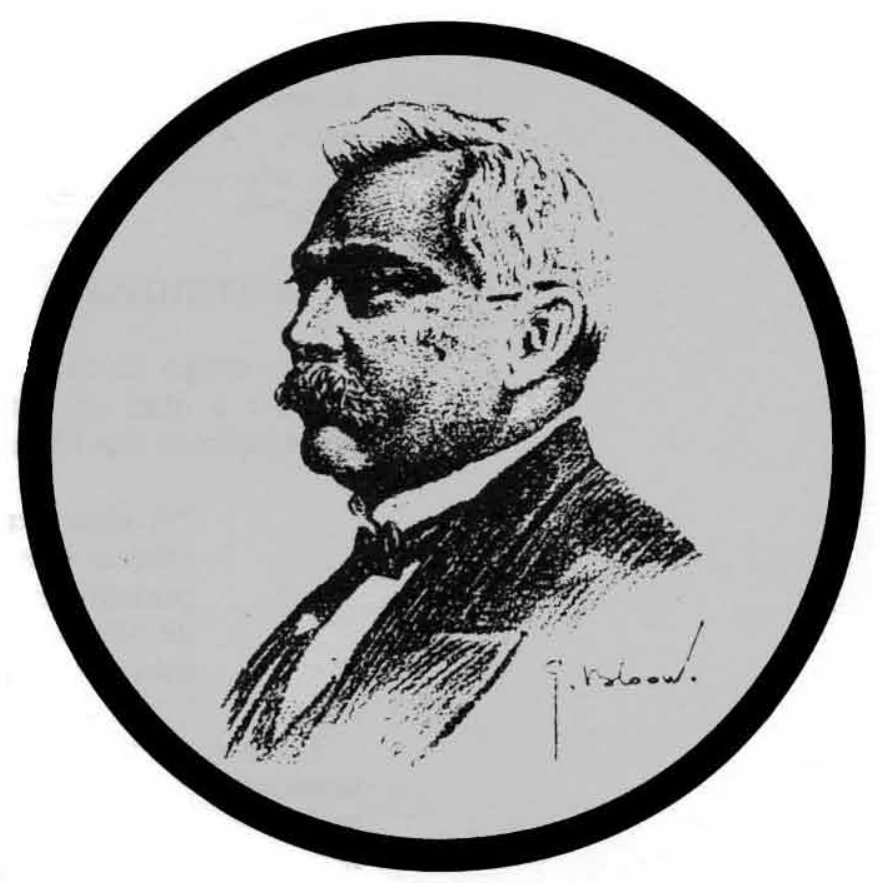

Antes de publicar "Machado de Assis" em 1897, Romero escreveu dois artigos sobre o escritor. Atacou, em 1870, o "lirismo subjetivista" e 0 "humorismo pretensioso" de "Falenas", segundo livro de poemas de Machado

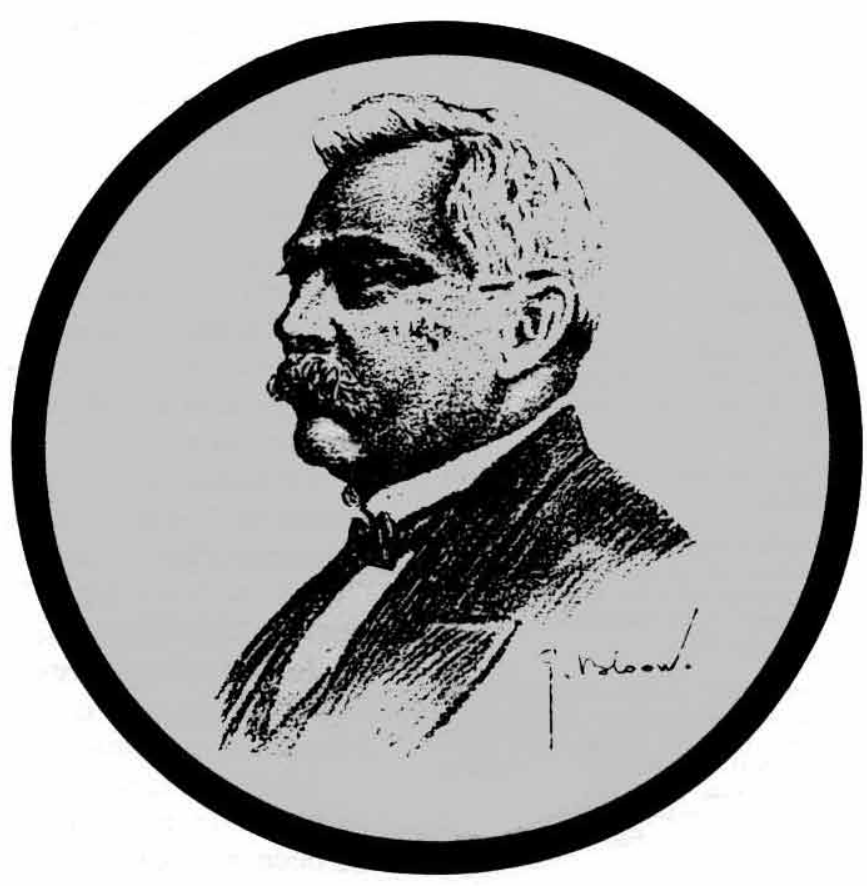

Dezembro Janeiro

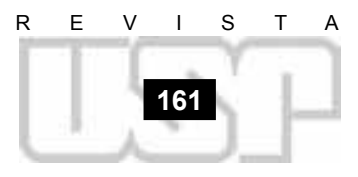


pois sua obra estaria em contradição com a lei do "consenso" de Spencer. Seu pessimismo teria, como origem, a impotência em acompanhar a "marcha das idéias modernas": "A prova mais evidente da negatividade de sua obra é que não teve continuadores, não teve nem poderá ter discípulos; porque ele nada inventou, não produziu uma só idéia"(8).

\title{
O Critério nacionalista
}

Em artigo sobre Quincas Borba, José Veríssimo afirmou a impossibilidade de se abordar a obra de Machado de Assis sob o critério nacionalista, pouco adequado a apreciação de sua literatura:

\begin{abstract}
“A obra literária do Sr. Machado de Assis não pode ser julgada segundo critério que peço licença para chamar nacionalístico. Esse critério, que é o princípio diretor da Historia da literatura brasileira e de toda a obra crítica de Sílvio Romero, consiste (...) em indagar o modo porque um escritor contribuiu para a determinação do caráter nacional’(9).
\end{abstract}

O nacionalismo é criticado por Veríssimo como critério por demais restrito, para constituir um princípio exclusivo ou dominante na crítica literária: "Estreitaríamos demais o campo de atividade literária dos nossos escritores se não quiséssemos reconhecer no talento com que uma obra é concebida e executada um critério do seu valor, independentemente de uma inspiração mais pegada à vida nacional"(10). Julgada pelo critêrio nacionalista, a obra de Machado seria "nula" ou "quase nula", o que mostraria quão "injusto" pode ser o "emprego sistemático de fơrmulas críticas". Sua literatura deve ser enfocada sob outra luz, pelo exame de sua concepção e modo de execução, não limitado à sua representatividade etnográfica ou nacionalista.

Veríssimo se afastou da ótica nacionalista, dominante na crítica do século XIX, voltada para a questão da diferenciação literária. Ao contrário de Romero, que inseria os autores em escolas literárias, que se sucediam umas às outras, Veríssimo não julgou, de modo negativo, o afastamento de Machado em relação às tendências vigentes à época, pois tomou, como critério de avaliação, a feitura da obra.

Veríssimo rompeu, em parte, com o naturalismo a partir da segunda série dos Estudos brasileiros de 1894, ao adotar uma linguagem impressionista e preocupações marcadas pela estética e retórica, que o afastaram das concepções críticas de Hippolyte Taine e Ferdinand Brunetière. Incorporou a crítica impressionista de Anatole France e Jules Lemaître, como forma de oposição ao cientificismo naturalista e substituiu disciplinas, como a biologia, fisiologia e sociologia, pela psicologia como instrumento de investigação $0^{(11)}$. Desse modo, procurou superar as limitaçōes da crítica naturalista da "geração de 1870". Prova dessa ruptura é seu ensaio sobre Quincas Borba de Machado de Assis, em que propôs o enfoque da realização literária ou estética das obras.

As diferenças de método crítico entre Romero e Veríssimo podem ser constatadas no confronto entre seus respectivos projetos de história literária. Na Historia da literatura brasileira (1888) de Romero, predominam os critérios naturalistas e sociológicos e uma concepção ampla de literatura, tomada como sinônimo de cultura. Já Veríssimo, na Historia da literatura brasileira (1916), atenuou o naturalismo, ao adotar a crítica impressionista e definir literatura, em termos estritos, como "arte da palavra", o que tornava possível o enfoque das questões literárias. Seu modelo é a Histoire de la littérature française (1894) de Gustave Lanson, que concilia o historicismo com a crítica impressionista.

Veríssimo adota um conceito estrito de literatura, que procurou definir em "Que é literatura?" e na introdução à sua História da literatura brasileira. Para tanto, recorreu a concepções estéticas e a noções da retórica clássica, caracterizando literatura como "boas ou belas letras", ou seja, arte da palavra com "artifícios de invenção e de composição"(12). Enquanto Romero se destaca no enfoque social da cultura, a contribuição de José Veríssimo reside na proposição de um ponto de vista específico para a história literária, em que o texto literário é abordado como entidade supostamente autônoma, cujo valor estético e significação se dariam de forma independente do contexto em que se insere, da situação em que as obras são escritas, lidas ou interpretadas.

Essa concepção do texto como entidade autônoma, endossada por Veríssimo, se liga às necessidades de legitimação da atividade crítica e literária e à definição de seu status 
frente às instituições. Para reconhecer a autoridade da crítica e do ensino de literatura, era preciso definir o seu campo de competência, de acordo com a identidade "natural" de seus objetos. $\mathrm{O}$ estabelecimento de atividades profissionais, relacionadas à literatura, depende da rede de inclusões e exclusões, através da qual se formam as matrizes institucionais que regulamentam as práticas de leitura e o cânone das obras integradas à história literária ${ }^{(13)}$.

Ao contrário de Veríssimo, Sńvio Romero não admite a exclusão de Machado do critério nacionalista: "Machado de Assis não sai fora da lei comum, não pode sair e ai dele, se saísse. Não teria valor”. O mérito dos autores deveria ser sempre o seu grau de contribuição à diferenciação nacional. Responde, assim, às críticas de Veríssimo à abordagem naturalista: "Por que motivo pode o autor de Várias historias [Machado] desmentir assim tão flagrantemente as leis do meio, da raça e do momento? Não haverá alguma ilusão em dâ-lo por tão distanciado de seu clima social?"(14).

\section{Humorismo e Pessimismo}

Os aspectos individuais da criação literária estão intimamente ligados, para Sńvio Romero, à ação dos fatores naturais, em especial da raça. Machado de Assis é abordado segundo um critério nacionalista, de base etnográfica, como representante da "sub-raça brasileira cruzada" que revelaria, junto com seus personagens, a "psicologia mestiça" do povo. Seu estilo é criticado pela ausência de colorido e de força imaginativa, pela falta de paisagem e natureza, e pela escassez das descrições. Afirma que o escritor, como mestiço, teria pouca facilidade no manejo do vocabulário e da frase, o que seria "a fotografia exata de seu espírito, de sua indole psicologica indecisa". Faz ainda alusão aos seus problemas na fala, ao sugerir que a gagueira se refletiria na escrita: "Vê-se que ele apalpa e tropeça, que sofre de uma perturbação qualquer nos órgãos da palavra. Sente-se o esforço, a luta"'(15).

Sílvio atacou o humor e a ironia em Machado, tidos como imitação afetada e pouco natural de autores ingleses, em particular o Thomas Sterne de The life and opinions of Tristram Shandy, que inspirou a forma digressiva e a quebra da cronologia das Memorias póstumas de Brás Cubas. O suposto artificialismo do humor machadiano, nas $\mathrm{Me}$ mórias póstumas e em Quincas Borba, é explicado a partir das hipóteses etnográficas sobre o caráter ariano e germano da ironia de Edmond Scherer e Hippolyte Taine, cuja introdução à Histoire de la litterature anglaise ecoa na História da literatura brasileira de Romero. O humor estaria, assim, em desacordo com a formação racial e o caráter brasileiro: "O temperamento, a psicologia do notável brasileiro não são os mais próprios para produzir o humour, essa particularíssima feição da índole de certos povos. Nossa raça em geral é incapaz de o produzir espontaneamente"(16).

$\mathrm{O}$ pessimismo de Machado de Assis é submetido à mesma análise etnográfica. Sílvio adverte que o brasileiro não ê um povo pessimista, por não apresentar, em sua "psicologia étnica", as tendências ao desalento mórbido è à resignação consciente diante das misérias da existência, presentes entre as raças arianas. Condena, de forma categórica, tanto o humorismo quanto o pessimismo de tais romances: "Machado de Assis (...) é quase mal quando se mete a filósofo pessimista, e a sujeito caprichosamente engraçado"(17).

A análise do humor e do pessimismo a partir de critérios etnográficos não é exclusiva a Sílvio Romero. Foi feita por críticos, como Araripe Júnior e José Veríssimo, que atribuíam menor importância ao fator racial. No ensaio sobre Quincas Borba, em que critica o enfoque nacionalista, Veríssimo recorreu a explicações de fundo racial, tomando o humor como "caracteristicamente germânico", e por isso mesmo "mais difícil de assimilar por povos como nós, de outra origem"'(18). Porém valorizou, ao contrário de Romero, a ironia na obra de Machado como ruptura com as condições etnográficas brasileiras.

Araripe, em artigo de 1895 sobre Quincas Borba, também abordou o humor em termos etnológicos. Para ele, a tendência ao humor não é característica do povo português, fazendo-se presente de modo exclusivo na raça anglo-saxônia. As literaturas neolatinas não comportariam a ironia com a mesma intensidade do que as literaturas de língua inglesa. Mas os escritores brasileiros seriam propensos à sátira e ao paradoxo devido às alterações sofridas pelo "caráter" português no meio tropical (19). Apesar das diferenças entre Romero, Verissimo e Araripe, todos abordaram a ironia machadiana a partir de critérios naturalistas, ainda que para mostrar, como é o caso de Veríssimo, a ruptura
13 Sobre a inserçấo institucional da interpretaçăo literária, cf. "Writing the history of criticism now?. D. La Capra, in History \& criticism, Ithace, pra, 11 Hnivery \& Cornell University Pross, 1985. InstiMinneapolis, University of Minnesota Press, 1987.

14 Machado de Assis, S. Romero, op. cit., pp. 17 e 344.

15 Machado de Assis, S. Romero, op. cit., pp. 81-2. Grifo meu.

16 Idem, ibidem, p. 133.

17 Idem, ibidem, p. 347

18 "O Sr. Machado de Assis", J. Verissimo, art. cit., p. 200 e segs.

19 "Machado de Assis" (1895), T. A. Araripe Jr., in Obra crfica. RJ, Casa de Rui Barbosa, 1958-70, p. 8, v. 3.5 v.

$\begin{array}{ll} & R \\ & \\ & \\ & \end{array}$


do escritor com o meio local. O que se pode criticar na abordagem de Sílvio Romero não é o uso dos modelos naturalistas, correntes à época, mas antes a sua incompreensão da literatura de Machado, que o levou a negar a pertinência da sátira e da quebra da narrativa tradicional nas Memorias póstumas de Brás Cubas e em Quincas Borba.

Como indica o subtítulo, Machado de Assis é um "estudo comparativo", em que Romero empregou os métodos das ciências naturais, para comparar, como um botânico ou zoologista, dois "espécimes" literários: Machado e Tobias Barreto. O critério cientrfico se converte em justificativa dos julgamentos de gosto do crítico que se afastava, com freqüência, da armadura naturalista, para emitir impressōes sobre a beleza das obras. O resvalo para o subjetivismo indica a oscilação, na crítica literária brasileira de fins do século XIX, entre dois polos: de um lado, o cientificismo naturalista, com suas pretensōes ao rigor e à imparcialidade; de outro, um subjetivismo impressionista, resultante da impossibilidade de se ater aos métodos adotados.

A oscilação entre naturalismo e impressionismo explica o descompasso existente em Sílvio Romero entre a investigação histórico-social e a atividade crítico-literária. Esse descompasso, observado por Araripe Júnior, Antonio Candido e Luiz Costa lima, o tornava mais agudo como historiador da cultura, ensaísta político e crítico de idéias, do que como crítico literário(20). Daí sua avaliação negativa de Machado de Assis e Castro Alves, tidos como inferiores ao "prógono" da Escola do Recife: Tobias Barreto de Menezes.

Romero admitiu que sua pouca empatia com o humor e o pessimismo de Machado era uma "simples impressão", sem a menor pretensão de que fosse aceita por todos. Mas recorreu ao naturalismo etnografico, para converter tais impressōes em júzos fundamentados, que explicam a suposta superioridade de Tobias Barreto sobre Machado como resultado da maior correspondência entre a literatura daquele e o "caráter mestiço" dos povos da América. Tobias teria contribuído para a evolução literária de sua época, ao fazer a ligação entre as correntes românticas e as modernas tendências naturalistas. Devido à amplitude da reação cultural lançada por Tobias Barreto, Sílvio lhe atribui o primeiro posto entre os intelectuais brasileiros do seu século.

\section{O POlemista Na ACADEmia}

Os ataques de Snlvio Romero a Machado de Assis se inserem na sua atitude de combate contra todas as formas de oligarquia, incluindo as panelinhas literárias. Em discurso de 1908, declarou ter lutado pelo completo afastamento dos bandos e grupos da atividade política e literária, recusando-se a pertencer a agrupamentos, com exceção da Academia Brasileira de Letras, "singular corporação eclética e amorfa", da qual apenas tomaria parte "por honra da firma", sem freqüentar suas sessões ${ }^{(21)}$. Os grupos literários são, segundo Romero, "verdadeiros clãs, em torno de alguns chefes, que se guerreiam uns aos outros e dão o santo e a senha para as exclusões dos que lhe não agradam"(22). Critica a turma de medalhões, liderada por Machado de Assis, com a participação de Veríssimo, Araripe, Joaquim Nabuco, Rui Barbosa, Lúcio de Mendonça, Capistrano de Abreu, João Ribeiro, Medeiros e Albuquerque, Graça Aranha e Oliveira Lima. Através desse grupo, fundador da Academia Brasileira de Letras, Machado exerceria "uma espécie de 'política dinástica' na literatura"(23).

Sflvio Romero proferiu o discurso de recepção a Euclides da Cunha na Academia Brasileira de Letras, em 18 de dezembro de 1906. Euclides, eleito em 1903, após o sucesso de público e de crítica de Os sertóes, ocupou a tribuna na cerimônia de posse e fez os elogios de praxe a seu antecessor, Valentim Magalhães, e ao patrono da cadeira, Castro Alves. Incumbido de saudar o novo membro da confraria, Romero se afastou do tom polido e cordial próprio aos discursos acadêmicos e causou agitação na platéia com suas críticas a Castro Alves e a Valentim Magalhães, aos escritores fluminenses, ao governo e até aos anarquistas... Ao seu lado, Medeiros e Albuquerque procurava desviar a atenção do público, fazendo tiras das folhas já lidas do longuíssimo discurso. A partir desse incidente, os discursos de recepção passaram a ser submetidos à leitura prévia do presidente da Academia ${ }^{(24)}$.

Com sua propensão ao escândalo, Romero criticou o governo na presença do presidente da República, Afonso Pena. Além disso, denunciou a imigração de frades e anarquistas, "obscurantistas refeces" e "desordeiros incuráveis", acolhidos pela nação brasileira para promover tumultos e greves. Como se discutia à época a lei de expulsão dos estrangeiros, o discurso acabou provocando indignação entre os socialistas e anarquis- 


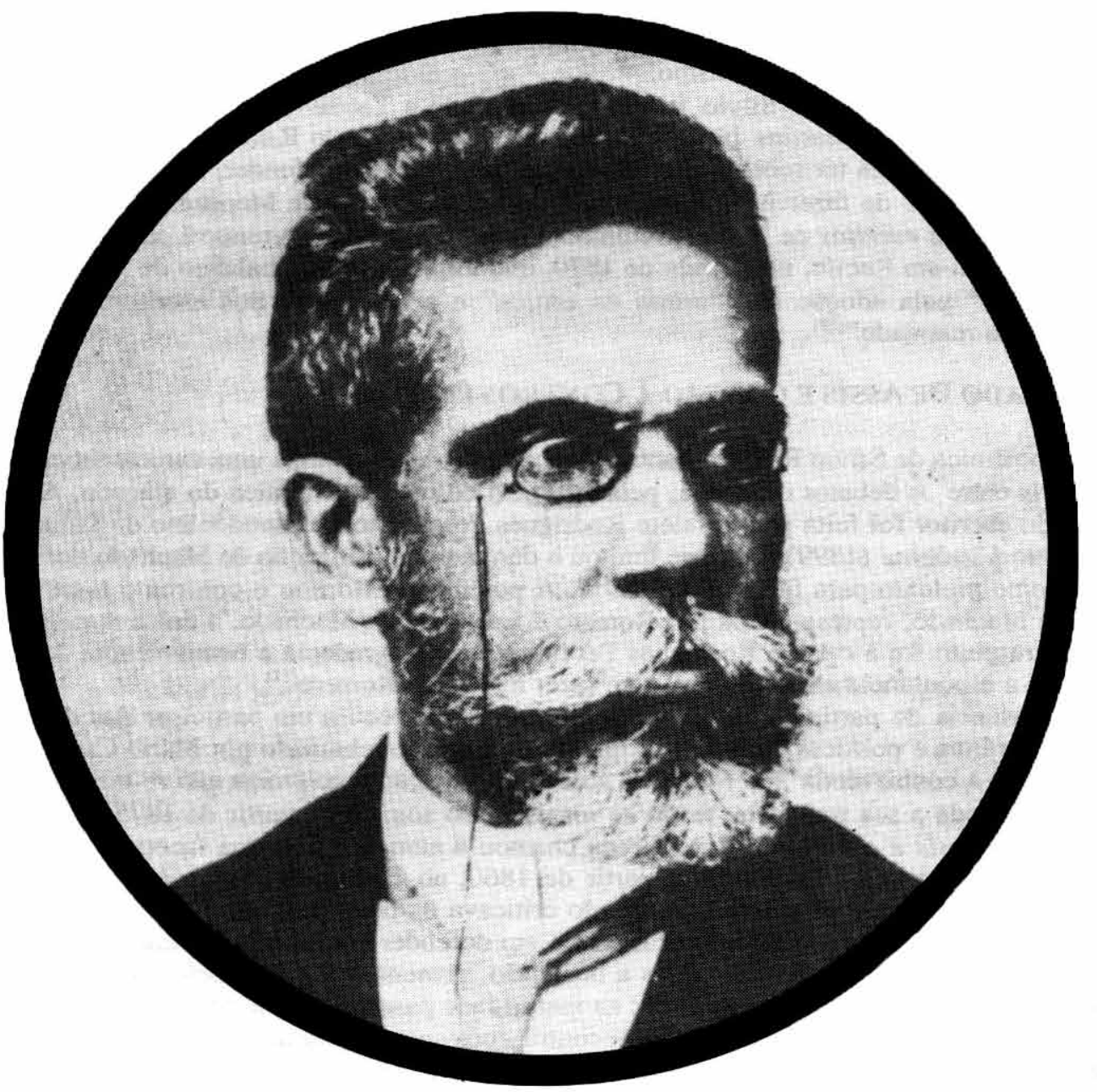

tas, que atacaram seu autor como reacionário no periódico Terra livre (25). $^{(2)}$

A Academia Brasileira de Letras foi fundada por iniciativa do grupo que se reunia na Revista Brasileira, da qual Veríssimo era diretor, para tomar chá e debater temas estéticos e literários, sem o envolvimento de questões políticas. Os acadêmicos buscavam o reconhecimento da criação literária e adotavam certa distância entre a sociedade e a sua própria esfera, mas não mais aceitavam a marginalidade, o patronato ou o engajamento. Sob a presidência de Machado de Assis, a Academia se tornou um salão de bom gosto, reuniāo de escritores com hábitos sóbrios, que não incluía combatentes raivosos como Romero.

A Academia Brasileira de Letras representou as tendências estéticas e as perspectivas de profissionalização do escritor na virada do século. Ao mesmo tempo, é sintoma da agonia da "geração de 1870", com suas concepçōes engajadas e combatentes, cuja luta pela "regeneração" nacional havia se dissipado na desilusão política nos anos 90 . Sua "missão" se tornara literária no sentido estrito, relacionada à afirmação profissional do crítico e do escritor ${ }^{(26)}$. Tal ceticismo foi pressentido por Veríssimo, que criticou, em 1889, o alcance limitado das propostas de modernização cultural.

Apesar de suas declarações de independência, Romero não escapava aos valores clânicos e oligárquicos criticados. Sua oposição à "panelinha" fluminense se tornou uma disputa entre grupos, em que a Escola do Recife contestava a influência dos escritores da Livraria Garnier e da Rua do Ouvidor, reunidos em torno de Machado de Assis e José Veríssimo. Em sua primeira obra, A filosofía no Brasil (1878), Sílvio já declarara sua oposição ao Rio de Janeiro e propusera uma "cruzada santa" contra a Corte, cuja "aura mórbida e corrupta" sufocaria as livres aspirações das províncias, sobretudo as do Norte(27). A abordagem da obra de Machado se converte no confronto entre o grupo fluminense e o movimento do Recife, que Carlos de Laet chamou, com malícia, de "escola teuto-sergipana", em alusão ao germanismo cultural e à naturalidade de seus líde-
Machado aos 60 anos, na época de Dom Casmurro

25 "Os disparates de um sábio", S. Alacid, in Terra livre (Såo Paulo), 22-25/jan./1902, pp. 1-2. Há outros artigos de critica a Romero nas ediçes de 6 de janeiro e de 5 de feve-

26 A tropical Belle Epoque: Elite culture and society in turn-of-the-century Rio de Janeiro, J. D. Needell. Cambridge, Cambridge University Press, 1987. Literatura como missâo: tensōes sociais e criaçăo cultural na Primeira República, N. Sevcenko. SP, Brasiliense, 1985.

27 A fllosofia no Brasil: ensaio crnt$\infty$. S. Romero. Porto Alegre, Tip. Deutsche Zeitung, 1878, pp. 112-3.

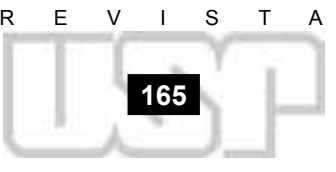


res. Romero contra-atacou e apelidou os escritores do Rio de Janeiro de "escola galofluminense", adepta do francesismo.

Machado de Assis, de Sílvio Romero, é dedicado a Tobias Barreto, Artur Orlando, Clóvis Beviláqua e Martins Júnior, participantes do grupo do Recife. Como um advogado, Romero julga ter recebido o "tríplice encargo" de se defender, de lutar pela Escola do Recife e de fazer justiça a seu chefe, Tobias Barreto de Menezes ${ }^{(28)}$. No prefácio aos Vários escritos de Tobias, retomou a defesa de seu conterrâneo e ressaltou a virada cultural em Recife, na década de 1870, que teria trazido o "balanço de nosso estado mental" pela adoção das "armas da crítica" e a orientação dos escritores para a "senda da realidade"(29).

\section{MACHADO DE ASSIS E O TÉdIO À CONTROVÉRSIA}

A polêmica de Snlvio Romero contra Machado de Assis assume uma característica sui generis entre os debates da época, pela ausência de qualquer réplica do atacado. A defesa do escritor foi feita por Lafaiete Rodrigues Pereira, sob o pseudônimo de Labieno, no livro Vindiciae (1899), onde se limitou a denunciar a utilização de Machado por Sñvio como pretexto para falar de Tobias ${ }^{(30)}$. A polêmica se tornou o confronto entre Tobias e Machado, representados por Romero e Labieno. De Machado, a única manifestação a respeito foi a carta a Rodrigues Pereira, em que agradecia a benevolência do seu juízo e a espontaneidade da defesa, sem fazer menção a Romero ${ }^{(31)}$.

A ausência de participação de Machado revela sua recusa em participar das discussões literárias e polf́ticas travadas na imprensa, o que foi chamado por Mário Casasanta de "tédio à controvérsia"(32). Mas essa atitude de rejeição à polêmica não se manteve ao longo de toda a sua trajetória, tendo se manifestado somente a partir de 1875 . Em Machado de Assis e a poltitica, Brito Broca chamou a atenção para uma faceta menos conhecida do escritor: sua atuação a partir de 1860, no Diário do Rio de Janeiro, como jornalista favorável aos liberais. Machado criticava os fatos políticos e se envolvia em debates, não hesitando em comprar brigas e em defender posições. Não tinha assumido ainda o pessimismo, o desencanto e a desilusão, presentes nas Memorias póstumas de Brás Cubas: "Na mocidade combatia; na maturidade passou a sorrir com descrença"(33).

A atitude combativa de Machado encontra correspondência no desfecho geralmente feliz de seus romances iniciais. Em A mão e a luva (1874), Luís Alves conquista, de modo calculado, a mão da mulher que ama e a cadeira de deputado a que aspira. A partir das Memórias póstumas, os anseios amorosos e a ambição política dos personagens são sistematicamente frustrados e se esfumam em ceticismo e desencanto, corroídos pela ironia dissolvente do narrador. A adoção literária da perspectiva cética coincidiu com o abandono das tendências combativas do jornalismo político da mocidade.

$\mathrm{Na}$ ficção de Machado, essa rejeição da polêmica se mostrou nas ironias ao debate cultural e político da época. Em A mão e a luva, satirizou os conflitos entre a "falange chartrônica" e o "regimento lagruísta", entre os que preferiam Chartron ou Mille. Lagrua como cantoras líricas ${ }^{(34)}$. Dá-se, no mesmo romance, o debate entre os que defendiam o direito de Sthephanoni ou de Mille. Lagrua à estréia da ópera Ernani de Verdi. Eram comuns tais discussões sobre as cantoras líricas: Tobias Barreto e Castro Alves, contemporâneos na Faculdade de Direito do Recife, romperam relaçōes por causa da disputa sobre as atrizes Adelaide do Amaral e Eugênia Câmara. Em Dom Casmurro (1899), de Machado, trava-se a polêmica entre Bentinho e Manduca sobre a guerra da Criméia. O debate, mantido por escrito, preenche os dias de Manduca, preso ao leito por doença, que defendia os aliados e a integridade da Turquia, enquanto Bentinho advogava o direito da Rússia.

A polêmica é ironizada por Machado de Assis como forma de debate, marcada pelo predomínio da retórica e pela irrelevância dos assuntos tratados. Na "Teoria do medalhão", satirizou os aspirantes à fama que, para parecerem ilustres ou notáveis e se elevarem acima da obscuridade geral, reduzem o intelecto à sobriedade e sufocam as próprias idéias, cuja ausência é dissimulada através da retórica ${ }^{(35)}$. A sátira à retórica e à polêmica faz parte da crítica ao personalismo do debate cultural e político, a serviço não da idéia, mas da glória e renome do orador, que encobre a vacuidade do pensamento pela dicção elevada e linguagem empolada ${ }^{(36)}$.

O "tédio à controvérsia" e o "silêncio do desdém", assumidos por Machado a partir de 1875, coincidem com seu progressivo afastamento da crítica literária. Seus artigos e ensaios críticos se tornaram escassos e passou a escrever apenas introduções e prefácios 
sob convite. O abandono da crítica e da polêmica, alêm de evitar inimizades que pudessem dificultar sua ascensão social e literária, se ligava ao ceticismo quanto às formas diretas de intervenção cultural e política. A descrença de Machado contrasta com a esperança e o otimismo de Romero com as transformações culturais e políticas ocorridas a partir dos anos 70 .

Machado de Assis remou contra a corrente, ao adotar um prisma cético e distanciado frente aos credos da época. No conto "Evolução", ridicularizou a propagação do evolucionismo de Spencer e as motivações pessoais de seus divulgadores. $\mathrm{O}$ deputado $\mathrm{Be}-$ nedito tem meteórica ascensão, ao repetir à exaustão o programa de expansão da rede ferroviária, ouvido por acaso em uma viagem de trem: “o Brasil é uma criança que engatinha; só começará a andar quanto estiver cortado de estradas de ferro...."(37). Os evolucionistas eram entusiastas da construção de estradas de ferro, que deveriam melhorar a "circulação" no organismo nacional, ao irrigar, como artérias e veias, as suas diversas partes, que poderiam assim progredir e se aperfeiçoar.

Descrente do caráter redentor das idéias e da eficácia das reformas sociais, Machado ironizou o naturalismo, o cientificismo, o abolicionismo e o republicanismo, nos chamados romances de segunda fase. Nas Memorias postumas de Brás Cubas e em Quincas Borba (1891), Quincas Borba é o arauto do Humanitismo, doutrina filosófica que reúne, de forma eclética e paródica, fragmentos da teoria evolucionista e da ideologia liberal, como o direito do vencedor às "batatas" conquistadas na luta pela existência, mesclados ao credo positivista, à lei dos três estados e à religião da Humanidade. Com tal mistura filosofica, atacou o cientificismo da "geração de 1870", o que explica parte da irritação que ambos os romances provocaram em Romero. Em Esaú e Jaco (1904) e Memorial de Aires (1908), as mudanças sociais e políticas trazidas com a abolição e a República foram tratadas de forma igualmente cética e irônica.

\section{A Palavra eficaz}

José Veríssimo reviu a questão da nacionalidade na literatura, ao romper com a crítica naturalista e cientificista e adotar métodos estéticos e impressionistas para a abordagem de objetos inapreensíveis segundo a ótica da "representatividade". Individualidades literárias, como Machado de Assis, estariam em ruptura com as condições impostas pela formação racial e pelo caráter brasileiro, ao escrever com os olhos postos no futuro, voltados não para os leitores presentes, mas para o público possível em um porvir mais ou menos remoto. Ao lançar um olhar distanciado, marcado pela ironia e pelo ceticismo, Machado se afastou do que Veríssimo chamou de "trabalho de gestação nacionalística", realizado após a proclamação da República ${ }^{(38)}$.

Veríssimo procurou separar as paixões culturais das preocupações políticas e afastar a literatura das deprimentes realidades da nação, para a qual lançava um olhar irônico e distanciado, que revelava a influência de Anatole France. Como forma de expurgar as "paixões do dia" e formar um ponto de vista imparcial, juntou à reflexão um "grão de ironia e de ceticismo", o que trouxe a desconfiança das reformas sociais e políticas e a consciência aguda da impossibilidade, ou pelo menos das limitações, da intervenção do artista e do intelectual na história ${ }^{(39)}$. Ao se distanciar das solicitações imediatas do meio e do momento, o escritor poderia romper com a ótica nacionalista, tornando sua obra dissonante frente à sociedade, o que tornaria inadequados os critérios naturalistas de representatividade. O “grão de ironia e ceticismo" de Veríssimo ou Machado excluem o sentimento de desilusão, pois não há qualquer adesão prévia ou esperançosa à sociedade forjada no 13 de maio e no 15 de novembro. Ao invés do entusiasmo de primeira hora, minado pela amargura das ilusões desfeitas, ambos desconfiavam das soluções apregoadas pela elite política.

Em conferência de 1883, Veríssimo elogiou a ruptura e a modernização trazidas pelo movimento intelectual da década de 70 , que teria abalado a cultura romântica e a erudição histórica e juŕ́dica. Mas, em 1889, no prefácio à primeira série dos Estudos brasileiros, abandonou tal otimismo e decretou o fim da renovação lançada pela "geração de 1870", que julgava impotente para evitar a estagnação que se anunciava no final dos anos $80^{(40)}$.

Em fevereiro de 1889, José Veríssimo considerava próximo o advento da República, sem aderir com entusiasmo às transformações políticas pressentidas. Embora considerasse inevitável a implantação do governo republicano no Brasil, mostrou-se cético e mesmo pessimista quanto a seus efeitos e encarava o movimento se não com hostilida-
37 "Evoluçăo", M. de Assis, in Rellquias da casa velha, Obra completa, op. cit., p. 708 , v. 2. No romance $A$ carne (1888), Júlio Ribeiro adotou concepçठes circulatórias e evolucionistas sobre as estradas de ferro, semelhantes às ironizadas por Machado.

38 Prefácio a Estudos brasileiros, $2^{\prime \prime}$ série (1889-1893), J. Veríssimo. RU/SP, Laemmert, 1894, p. ix.

39 Idem, ibidem, pp. viii-ix. Sobre a relaçăo entre ironia, ceticismo e pessimismo em José Verissimo, cf. A tradiçăo do impasse, J. A. Barbosa, op. cit., p. 113 e segs.

40 "O movimento intelectual brasileiro nos últimos dez anos" (1883), J. Veríssimo, in Estudos brasileiros (1877-1885). Pará, Tavares Cardoso, 1889. Prefácio a Estudos brasileiros, idem, pp. xviii-xix.

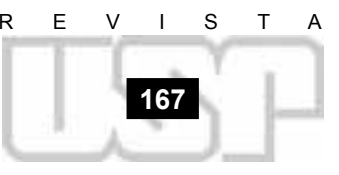


41 Idem, Ibldem, pp. xili-xvil.

42 "Mensagem dos Homens de Letras do Rio de Janeiro ao Governo Provisorio da República" (1889), S. Romero, in Novos estudos de IIterature contemporanea. RW, Garnier, 1898, pp. 259-64.

43 Prefácio a Estudos brasileiros (1889), J. Verissimo, op. cit., p. x.

44 Ensalo de filosofia do direito, $S$. Romero. RJ, Cunha \& Irmáos, 1895 p. 228. "O elemento plebeu na literatura do Brasil", idem, in Estudos de literatura contemporanea: páginas de crfica. RJ, Laemmert, 1885, P. 157. Historia da literatura brasileira. idem, op. cit., p. 192, v. 2.

45 "Sobre Machado de Assis e Luiz Delfino" (1882), S. Romero, art. cit. p. 233. Machado de Assis (1897), idem, op. cit., p. 4. de, pelo menos sem simpatia. Em sua opinião, a República não seria muito diversa da monarquia, pois participariam do novo regime homens com a mesma educação, índole, costumes e tendências dos representantes do antigo sistema político: "Tudo isto, ao meu parecer, ao menos, não promete uma república muito inteligente nem sensivelmente diversa da monarquia atual"(41). Veríssimo não acreditava nas mudanças sociais e políticas que não fossem acompanhadas de uma reforma da inteligência e da educação, capaz de alterar os indivíduos junto com as instituições.

Sílvio Romero, por sua vez, saudou o novo regime, repleto de euforia e esperança, na "Mensagem dos homens de letras do Rio de Janeiro ao Governo Provisório da República", que redigiu e publicou nos jornais cariocas em 22 de novembro de 1889 . Sílvio atribuiu ao homem de letras e ao seu engajamento histórico um papel de destaque no movimento, cujo êxito lançaria a pátria e a literatura na trilha do progresso. Referese à "pena" dos escritores como "arma" de grande eficácia na preparação da reforma em curso: "Nunca esta arma foi manejada por mãos mais destras e punhos mais seguros. (...) Não existe gládio mais formidável do que a pena"(42).

Ao anunciar o esgotamento da “geração de 1870”, Veríssimo se mostrou cético quanto à eficácia da cultura escrita no Brasil: "A literatura (...) ê sem ação ou influência em um povo, como o nosso, que não lê e nem ao menos possui bastante desenvolvido e forte o sentir nacional para, a exemplo de outros, receber dos seus escritores e pensadores, por uma espécie de assimilação inconsciente, ensinamentos e ditames". Sobre o papel dos escritores na proclamação, observou: "Não cabe talvez à literatura parte alguma no movimento social notado"(43). Mas essa pouca repercussão da atividade literária não estaria restrita aos primórdios da República, sendo uma constante na história do país.

Descrente quanto à ação ou à influência das letras, Veríssimo considerava os movimentos culturais mais "produtos" do que "fatores" dos fenômenos sociais. A cultura literária nacional seria o reflexo da sociedade, com alcance reduzido ou nulo, incapaz de influenciar ou determinar os acontecimentos políticos. A República não resultaria, em sua interpretação, da renovação cultural da "geração de 1870", esgotada nos anos 80. Essa descrença quanto à eficácia da palavra escrita limitou sua compreensão das relações entre literatura e sociedade, na medida em que exclui, ou pelo menos reduz, a ação daquela sobre esta. Mas rompeu, a partir desse ceticismo, com a visão romântica sobre a influência das letras no progresso social e com o cientificismo missionário de Romero. Veríssimo libertou a literatura do imediatismo político e da representação nacionalista, o que tornava possível a reflexão sobre a sua especificidade.

A posição de José Veríssimo introduziu tensão no modelo intelectual da "geração de 1870", marcado pelo tom empenhado e participante. Enquanto Romero defendia a pregação de doutrinas através da crítica e da polêmica, Veríssimo inverteu esse modelo, ao condenar, como infrutíferas, as intervenções orientadas pelas paixões do momento, ou os compromissos estéticos ditados pelas contingências do presente. Desse modo, a crítica de Veríssimo se aproximou da ficção de Machado de Assis, seu objeto privilegiado. Ambos pensaram a literatura brasileira como expressão nacional dotada de caráter universal e propuseram uma consciência estética, relacionada às tentativas de profissionalização do escritor.

A recusa de Machado à polêmica colidiu com os valores éticos e científicos de Sílvio Romero que, apoiado em argumentos evolucionistas, erigia o debate de idéias em modelo de intervenção do intelectual na história. A polêmica corresponderia, no plano cultural, aos processos teleológicos de aperfeiçoamento das espécies na natureza. Enquanto parte da "luta pela existência", o debate traria a evolução do pensamento, promovendo a "seleção" e "depuração" das idéias. A "luta das idéias" permitiria ao escritor romper, pela atuação conjunta da crítica e da polêmica, a indiferença do público pela literatura ${ }^{(44)}$.

Ao valorizar a luta e a polêmica, Romero interpretou negativamente a ausência de participação de Machado nos debates de seu tempo. Essa ausência é tomada, junto com o suposto atraso do escritor, como indício de indefinição e acomodação: "Sem convicções políticas, literárias ou filosóficas, não é, nunca foi, um lutador". Essa afirmativa, presente em artigo de 1882, ecoou na obra de 1897 sobre Machado: "Dar uma lacuna em sua carreira e uma falha em sua obra: não teve o momento de luta, o aprendizado do combate, nunca se viu contestado, nunca teve de terçar armas"(45). Mas, apesar do convite ao duelo, Machado de Assis se recusou a tomar a defesa de sua obra, optando pelo silêncio do desdém e pelo sorrir da descrença. 